Boletín de la Sociedad Geológica Mexicana

VOLUMEN 65, NÚM. 2, 2013, P. 285-298

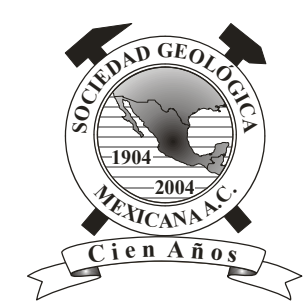

\title{
A proposal for a new family: Montezumellidae (Crustacea, Decapoda, Brachyura) and description of new genus and species Moianella cervantesi from the Priabonian (late Eocene) of Catalonia (NE of Iberian Peninsula)
}

\author{
Àlex Ossó1,*, José Luis Domínguez² \\ ${ }^{1}$ J.V.Foix, 12-H, 1er-1 ${ }^{\mathrm{a}} .43007$ Tarragona, Catalonia. \\ ${ }^{2}$ Padre Manjón, 12. 50010 Zaragoza, Spain. \\ *aosso@comt.cat
}

\begin{abstract}
A new brachyuran family is proposed in order to accommodate Montezumella Rathbun, 1930, previously assigned to Cheiragonidae Ortmann, 1893. The establishment of Montezumellidae n. fam. is based on the examination of several samples of both sexes of Montezumella, with well-preserved thoracic and abdominal structures. A new genus and species, Moianella cervantesi n. gen., n. sp. from the Priabonian (late Eocene) transitional levels of central Catalonia (NE of Iberian Peninsula) is described herein and assigned to the new family. The taxonomic placement of Montezumellidae n. fam. is discussed. Furthermore, "Atelecyclus" gorodiskii Rémy, 1959 in Gorodiski and Rémy, 1959, considered as atelecyclid, is herein attributed with reserve into the new family.
\end{abstract}

Keywords: Montezumellidae, Cheiragonidae, Cancroidea, Montezumella, Moianella, Priabonian, Eocene.

\section{Resumen}

Se propone una nueva familia de decápodos braquiuros para acomodar el género Montezumella Rathbun, 1930, últimamente asignado a Cheiragonidae Ortmann, 1893, como resultado de las observaciones efectuadas en ejemplares de ambos sexos de ese género, con las estructuras torácicas y abdominales perfectamente conservadas. Se describe también, un nuevo decápodo braquiuro, Moianella cervantesi $n$. gen., $n$. sp. procedente de los niveles transicionales del Priaboniano (Eoceno tardio) de la Cataluña central (NE de la Península Ibérica) que se asigna a la nueva familia. Además, “Atelecyclus” gorodiskii Rémy, 1959 in Gorodiski and Rémy, 1959, considerado atelecíclido, es asignado con reservas a la nueva familia.

Palabras Clave: Montezumellidae, Cheiragonidae, Cancroidea, Montezumella, Moianella, Priaboniano, Eoceno. 


\section{Introduction}

The recent discovery of Moianella cervantesi $\mathrm{n}$. gen., n. sp. in the transitional levels of the late Eocene (Priabonian) near the village of Moià, region of Moianès (Bages, Catalonia, NE of Iberian Peninsula) increases the list of decapod taxa known from this area, which was widely studied and described by Via (1932, 1941, 1948a, 1948b, 1959). This species represents one of the youngest decapod of Vic-Igualada area (central Catalonia). Via (1988) pointed out the presence of several specimens of Portunus catalaunicus Via, 1941, in the highest marine Eocene levels of several localities of this area and named it "Collbàs residual carcinic fauna", and reported a probable age of Priabonian for those levels, which has been recently confirmed (Cascella and Dinarès-Turell, 2009).

Moianella cervantesi n. gen., n. sp., represented by two well preserved specimens, is strongly related to Montezumella Rathbun, 1930 (1930b), an extinct genus assigned to Cheiragonidae Ortmann, 1893, during the last decade and claimed as the first cheiragonid in the fossil record. This study permits to compare either genera and in particular to revise Montezumella. A thorough examination of very well-preserved specimens of different species of Montezumella, from Vic and Igualada areas (Catalonia, Iberian Peninsula), from other areas of Ebro foreland basin (Huesca, Aragón, Spain), and also from the Vicenza region (Italy), allows examination of the ventral features of the females. The vulvae are located, as usual in Brachyura, inside of the sterno-abdominal cavity and are completely covered by the abdominal somites, instead of being exposed as in Cheiragonidae; the supra-orbital structure consists of three orbital spines and two fissures, and the posterolateral margin is unarmed. As a result, based on these key characters, in addition to some others, we propose removing definitively Montezumella from Cheiragonidae, and suggest its placement together with Moianella n.gen. within its own family, Montezumellidae n. fam.

\section{Geological setting}

The fossil bearing outcrop is located in the Vic area, between the Cadí thrust sheet and the Catalan Coastal Ranges (Serra-Kiel et al., 2003). This is in the north eastern part of the Ebro foreland basin, whose origin is related to flexural subsidence due to the collision between the Eurasian and Iberian plates from the Late Cretaceous to the Miocene. During the Paleogene the basin formed an Atlantic gulf; marine sediments filled the basin until the Late Eocene, after which only non-marine facies deposited (Puigdefabregas et al., 1992). Many depositional successions during the Paleogene, in this part of the basin, are related to the emplacement of the south Pyrenean thrust sheets which are linked to two major relative sea level rises, in the Lower Ypresian (early Eocene) and Bartonian (middle-late Eocene). The depositional succession ends in the late Eocene with the closure of Ebro foreland basin to marine influence and its filling with lacustrine and alluvial deposits (Puigdefàbregas et al., 1986; Sanjuán et al., 2012) (Figure 1).

Layers-bearing crabs correspond to the so-called Terminal Complex, at the end of the marine sedimentation in this zone of the basin. This unit, defined by Travé (1992) and Travé et al. (1996), is made up of sandstone, anoxic marl, limestone including freshwater stromatoliths, and gypsum, representing the progressive filling of the basin and its final shift to non-marine conditions (Sanjuán et al., 2012) (Figure 2).

According to Travé (1992) and Travé et al. (1994, 1996), facies of Terminal Complex cropping out near Moià, consist of three carbonate units that represent successive shallowing carbonate platforms interlayered with prograding sediments in distal areas. Coralline algal build-ups capped by ostreid and echinoid bearing layers are included in the Lower Carbonate Unit, while coralline algal build-ups, oolitic bars, and meadows of branching corals are present in the Middle Carbonate Unit, and laminated microbial intervals composes the Upper Carbonate Unit. Crabs specimens were found in the bioherms formed by the articulated corallinealgae Corallina sp. and Jania sp., the crustose coralline algae Lithoporella sp. and Lithothamnion sp. of the Middle Carbonate Unit. Bivalves and echinoids complete the association (Figure 3).

The stratigraphic positions of these units suggest that the Terminal Complex belongs to an intermediate sequence, which has been controversially considered late Bartonian or early Priabonian in age (Serra-Kiel et al., 2003). Recent studies by Cascella and Dinarès-Turell (2009) on calcareous nannofossils have revealed the presence of the lower Priabonian in marine rocks of this part of the basin (Sanjuán et al., 2012).

\section{Montezumellidae n. fam.}

Type genus: Montezumella Rathbun, 1930

Included genera: Montezumella Rathbun, 1930, Moianella n. gen., Atelecyclus gorodisklii Rémy, 1959 in Gorodiski and Rémy, 1959, is attributed with reservation to the family as "Atelecyclus" gorodiskii.

Diagnosis: Carapace from medium size (Montezumella) to large size (Moianella), from elongate to ovate subhexagonal shape, from slightly longer than wide to as wide as long, almost flattened, slightly convex longitudinally, somewhat less convex in transverse section; surface with tubercles and granules, usually in the anterior half of carapace, and rows of granules forming short ridges of squamous aspect in the posterior half. Regions well defined by shallow grooves, usually smooth. Dorsal regions well marked; hepatic region slightly swollen; protogastric lobes inflated, anterior half of lobes both subdivided longitudinally 


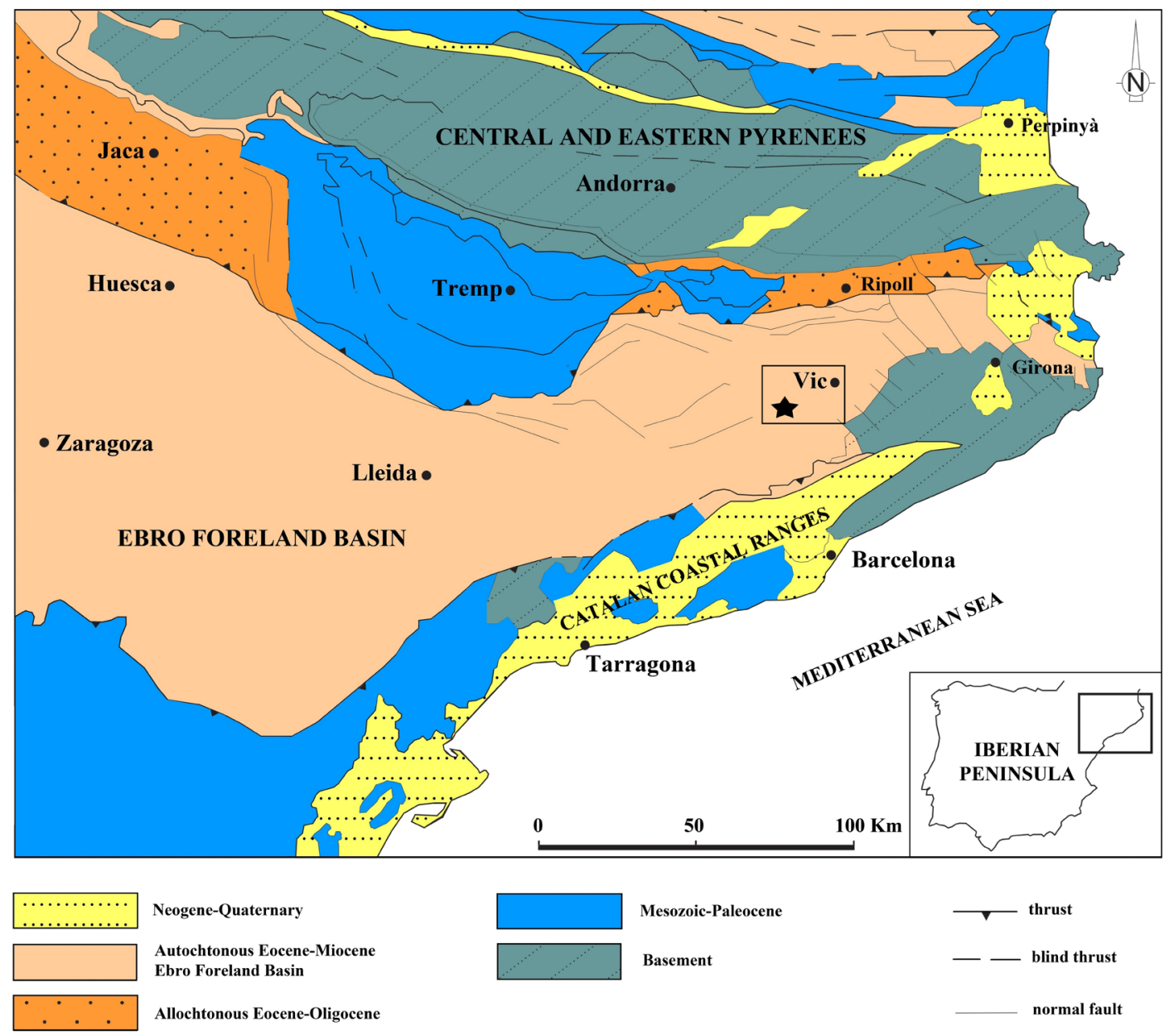

Figure 1. Location map and geological sketch of the eastern part of the Ebro foreland basin showing the location of the outcrop area studied (modified from Sanjuán et al., 2012 and Vergés et al., 1998, in Geological Society, 134 (Special Publications), reproduced with permission of Geologica Acta).

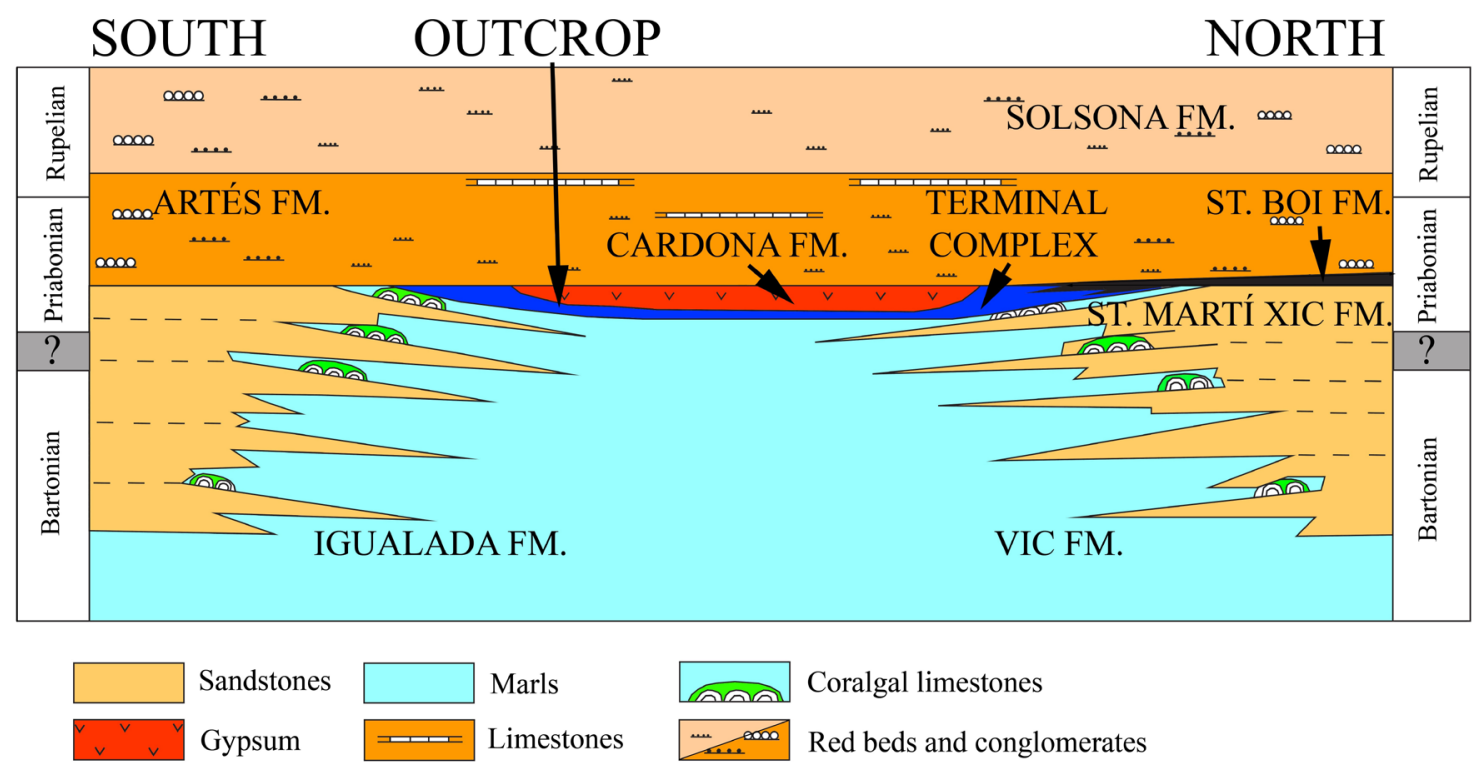

Figure 2. Stratigraphic framework of the Eocene in the outcrop area (modified from Sanjuán et al., 2012 and Vergés et al., 1998, in Geological Society, 134 (Special Publications), reproduced with permission of Geologica Acta). 


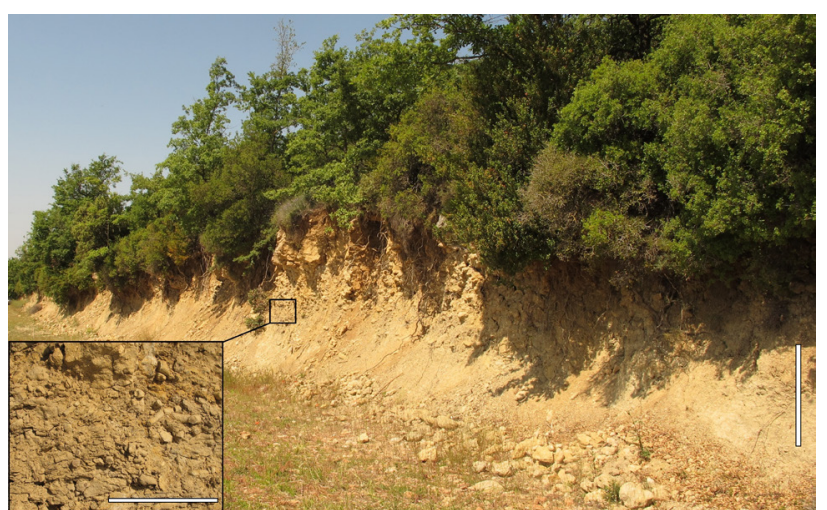

Figure 3. View of typical aspect of outcrop and close up showing the coralline algae bioherm. Scale bar is $1 \mathrm{~m}, 10 \mathrm{~cm}$ in square close up.

by a median groove forming four short ridges reaching the four frontal lobes or teeth respectively; mesogastric region sharp, reaching the frontal margin; metagastric regions inflated; urogastric region narrow, both well delimited transversally, bounded laterally by a groove connecting the gastro-hepatic and cervical groove to the branchiocardiac groove, forming a characteristic continuous parallel axial line. Cardiac region large. Intestinal region flat. Epibranchial lobes inflated. Mesobranchial and metabranchial region slightly inflated. Front wide, four-lobed or four-toothed, axially divided by a notch. Orbits oblique, oval, complete, supra-orbital margin with three teeth or spines separated by two fissures; inner orbital tooth subtriangular; supraorbital tooth blunt to sharp; outer orbital tooth sharp, usually sunken; continuous serrated orbital corner and infra-orbital margin bearing a prominent infra orbital tooth. Anterolateral margin short, straight to slightly convex, with four teeth (excluding the outer orbital tooth) forward directed, subequal or decreasing in size, the latter being the smaller. Posterolateral margin straight to convex, unarmed, stepped, edge decorated with tubercles or ridges; a marked re-entrant of fifth pereiopod. Posterior margin from straight to slightly concave, short, rimmed. Male thoracic sternum narrow, elongate, entirely metamerised (except for suture $1 / 2$ and suture $3 / 4$ that is only present laterally). Sutures $2 / 3$ and $4 / 5$ to $7 / 8$ complete; episternites well developed, delimited by complete sutures. Sterno-abdominal cavity deep, narrow, $\mathrm{V}$-shaped, reaching the half of sternite 4. Sternites 1 and 2 subtriangular; sternite 3 short, wide, separated laterally from sternite 4 by a notch; sternite 4 elongate; sternites 5, 6, 7 subtrapezoidal; sternite 8 not known. Median line present along the sternite 8 to the half of sternite 4 . Press-button on sternite 5 close to suture 5/6. Male abdomen narrow, with all free somites and telson; somites rectangular, somite 6 elongate. Female thoracic sternum larger than in males. Vulvae small, located inside deep sterno-abdominal cavity on somite 6 close to suture $5 / 6$, completely covered by wide, subtrapezoidal somite 6 . Ischium of third maxiliped with markedly convex inner margin. Chelipeds strong, slightly heterochelous in males and females. Merus robust, not fused with basis-ischium, subtriangular in section, inner surface concave, outer surface granulated and ridged. Carpus strong, massive, densely granulated to tuberculated, upper margin with two forward directed spines on inner and outer angles. Propodus strong, upper margin strongly tuberculated, outer margin convex, with two marked transverse carinae, the second one reaching the tip of fixed finger; dactylus curved, long as propodus length, proximal third of upper margin spiny; both, fixed finger and dactylus almost homodontous, the central tooth being slightly more developed. Ambulatory legs long, robust, sub-oval in section, dactylus long; acute lanceolate.

\subsection{Historical account of Montezumella Rathbun, 1930} and allied genera.

Montezumella Rathbun, 1930, was erected to accommodate Montezumella tubulata Rathbun, 1930 (1930b, p. 4, pl. 2), from the Eocene of Baja California (México), which is therefore the type species. The genus was originally related to Erimacrus Benedict, 1892, a genus considered at that time to belong to Atelecyclidae Ortmann, 1893. In addition, Rathbun (1930b, p. 4) included Cancer fraasi Lörenthey, 1909 (Lörenthey, 1909, T. 2 f. 3a, 3b) from the Eocene of Egypt in Montezumella as $M$. fraasi (Lörenthey, 1909). Successive works describing new species of Montezumella retained the genus into Atelecyclidae: $M$. rutteni Van Straelen, 1933, from late Eocene of Netherlands Antilles; M. lamiensis Rathbun, 1934, from Neogene of Fiji; M. casayetensis Rathbun, 1937, from late Oligocene of Panamá; M. amenosi, Via, 1959, from the Eocene of Catalonia; M. scabra Quayle and Collins, 1981, from the Eocene of United Kingdom. Also, Quayle and Collins (1981, p. 748) referred Titanocarcinus elegans Lörenthey in Lörenthey and Beurlen, 1929, from Eocene of Hungary, to Montezumella elegans (Lörenthey in Lörenthey and Beurlen, 1929).

Via (1970, p. 14-15) noted the differences between Montezumella and Erimacrus, and suggested a phyletic relationship between Montezumella and the extant Atelecyclus as well as other genera considered at that time as atelecyclids.

More recently, Schweitzer and Salva (2000), based on superficial similarities, reassigned Montezumella to the family Cheiragonidae Ortmann, 1893 (= Telmessinae Guinot, 1977) (see Števčić, 1988). Subsequent authors followed this new classification when describing new species referable to Montezumella: M. eichorni Schweitzer and Salva, 2000, from the Eocene of United States; $M$. microporosa Portell and Collins, 2002, from the late Eocene of United States; M. pumicosa Beschin, Busulini, De Angeli and Tessier, 2002, from the middle Eocene of Italy. All authors in successive investigations have considered all species of Montezumella as member of Cheiragonidae. Other genera were included in this family: Karasawaia Vega, Nyborg, Coutiño and Hernández-Monzón, 2008, 
Pirulella Feldmann, Schweitzer and Encinas, 2010, and Stintonius Collins, 2002 (see Schweitzer et al., 2010).

3.2. Distinctive characters between Montezumellidae nov. fam. and Cheiragonidae

The establishment of the new family Montezumellidae nov. fam. is justified by a series of characters that are unique and distinguish it from the Cheiragonidae.

The Cheiragonidae (= Telmessinae Guinot, 1977; Števčić, 1988) consists of two extant taxa, Telmessus White, 1846, and Erimacrus Benedict, 1892. It was previously included in Corystoidea Samouelle, 1819 (Bouvier, 1942) or to Cancroidea Latreille, 1802 (Števčić, 2005; Vega et al., 2008; Schweitzer et al., 2010). A suprafamilial rank, Cheiragonoidea Ortmann, 1893, was proposed by Ng, Guinot and Davie (2008, p. 55) and adopted by De Grave et al. (2009, p. 31).

The original description by Rathbun (1930b, p. 4) indicates for Montezumella: "In shape and ornamentation of carapace resembling Erimacrus but differing in the orbit which is broadly tubular viewed from above, concealing the eye. Postero-lateral margins of carapace unarmed." Therefore, with this sentence, Rathbun noted the superficial similarities but also the important differences.

Members of Cheiragonidae possess bi-lobed or fourlobed front (Benedict, 1892; Števčić, 2005) whereas the front is always four-lobed or four-toothed in Montezumellidae. Other differences in the armature of lateral margin in both families are evident: for example, a number of six or seven antero- and postero-lateral teeth in Cheiragonidae (see Benedict, 1892) instead of four exclusively anterolateral teeth in Montezumellidae, without teeth present on posterolateral margin. This distinctive character was pointed out by Via $(1969$, p. $187 ; 1970$, p. 14) and is corroborated by the material examined by us and figured here (Fig. 4).

The pattern of fronto-orbital margin of Montezumellidae and Cheiragonidae would seem identical, mainly regarding the inner orbital tooth which are stout, acute subtriangular and with serrated outer margin. Both families share the same supra-orbital pattern: trilobed with two fissures. Although some authors claim that there are only one fissure and outer and inner orbital spines (Schweitzer and Salva, 2000, p. 286, 287; Karasawa and Schweitzer, 2004), careful observation of figures of Benedict, 1892 (Pl. 15-16-17), descriptions of Števčić $(2005$, p. 32) and pers. comm. of Guinot (2012) indicate a trilobed nature of the supra-orbital margin in Cheiragonidae. The supra-orbital margin in Montezumellidae, presents an outer orbital tooth, usually sunken and at lower level than the other teeth, so that it was often not seen or misinterpreted. For example Rathbun (1930b, p. 4) recognized only two teeth when she described Montezumella tubulata. According to the description of Via (1959, p. 46), M. amenosi Via, 1959, has two teeth and one notch but three teeth have been, however, illustrated (see Via, 1969, p. 184; 1970, p. 13, f. 1). Beschin et al. (2002, p. 16) also pointed out only one fissure when described M. pumicosa Beschin, Busulini, De Angeli and Tessier, 2002. Collins and Donovan (2005, p.4) suggested only one supra-orbital notch in M. rutteni Van Straelen, 1933. De Angeli (1995, p. 15) observed three teeth and two fissures in M. elegans (Lörenthey and Beurlen, 1929) whereas a similar structure was noted by Portell and Collins (2002, p. 597) in M. microporosa Portell and Collins, 2002. In contrast to the similarities in the supra-orbital margin, the infra-orbital margin of both families is clearly distinctive. The orbits are not complete and the eyes are not protected either dorsally or ventrally in Cheiragonidae (Benedict, 1892, P. 16, f. 2-5; Števčić, 2005, p. 32.) whereas the orbits are complete in Montezumellidae (Figure 4: b'- d'; 6: c'). This is an important difference between the two families.

In addition, the most important and definitive differences between Cheiragonidae and Montezumellidae are the sternal and abdominal features. In the two genera of Cheiragonidae (Telmessus White, 1846, and Erimacrus Benedict, 1892) the females have the vulvae located laterally on the sternite 6 that are not covered by the abdomen, and thus exposed (Benedict, 1892, p. 223, Pl. 16, f. 3-6; Guinot, 1979, p. 178, Pl. 25, f. 1-2-3; Števčić, 1988, p. 32, 2005, p. 32; Schweitzer and Salva, 2000, p. 285; Karasawa and Schweitzer, 2004, p. 114). In Telmessus, the vulvae are even located in a strong notch that cuts the external margin of abdominal somite 6 (Guinot, 1979, p. 25, f. 3). This character is almost unique amongst the Brachyura (Guinot, 1979, p. 178). In contrast, the vulvae of Montezumellidae are located inside the sternoabdominal cavity and completely covered by the abdomen, as usual in Brachyura (Figure 5: b-b'-c-d-e).

Other differences between Cheiragonidae and Montezumellidae are clear when features of the thoracic sternum are considered. The pattern of the sternal sutures is different. In Cheiragonidae, the sutures $4 / 5$ and $5 / 6$ are incomplete, with extremities that are close to each other, and sutures 6/7 and 7/8 are complete (Guinot, 1979, p. 99). In Montezumellidae sutures $4 / 5$ to $7 / 8$ are complete (Figure 5: a). In addition, males of Cheiragonidea have a large, triangular abdomen, with abdominal somites 3-5 fused (Števčić, 2005, p. 32) while in Montezumellidae the abdomen is narrow, with all somites free in Montezumellidae (Via, 1969, p.13, f. 2a; 1970, f. 2).

These characteristics seem to be sufficient to remove Montezumella from Cheiragonidae Ortmann, 1893, and are evidence of a separate family, justifying the establishment of Montezumellidae $\mathrm{n}$. fam.

Another genus, Moianella $\mathrm{n}$. gen. that offers the same diagnostic familial characters as Montezumella is assigned here to Montezumellidae $\mathrm{n}$. fam. (see below).

When the diagnosis of Cheiragonidae Ortmann, 1893, was expanded in order to include a different range of characters (Schweitzer and Salva, 2000, p. 287; Karasawa and Schweitzer, 2004, p. 144-145), a number of fossil genera from Eocene were moved or added to this family. Karasawia Vega, Nyborg, Coutiño and Hernández-Monzón, 

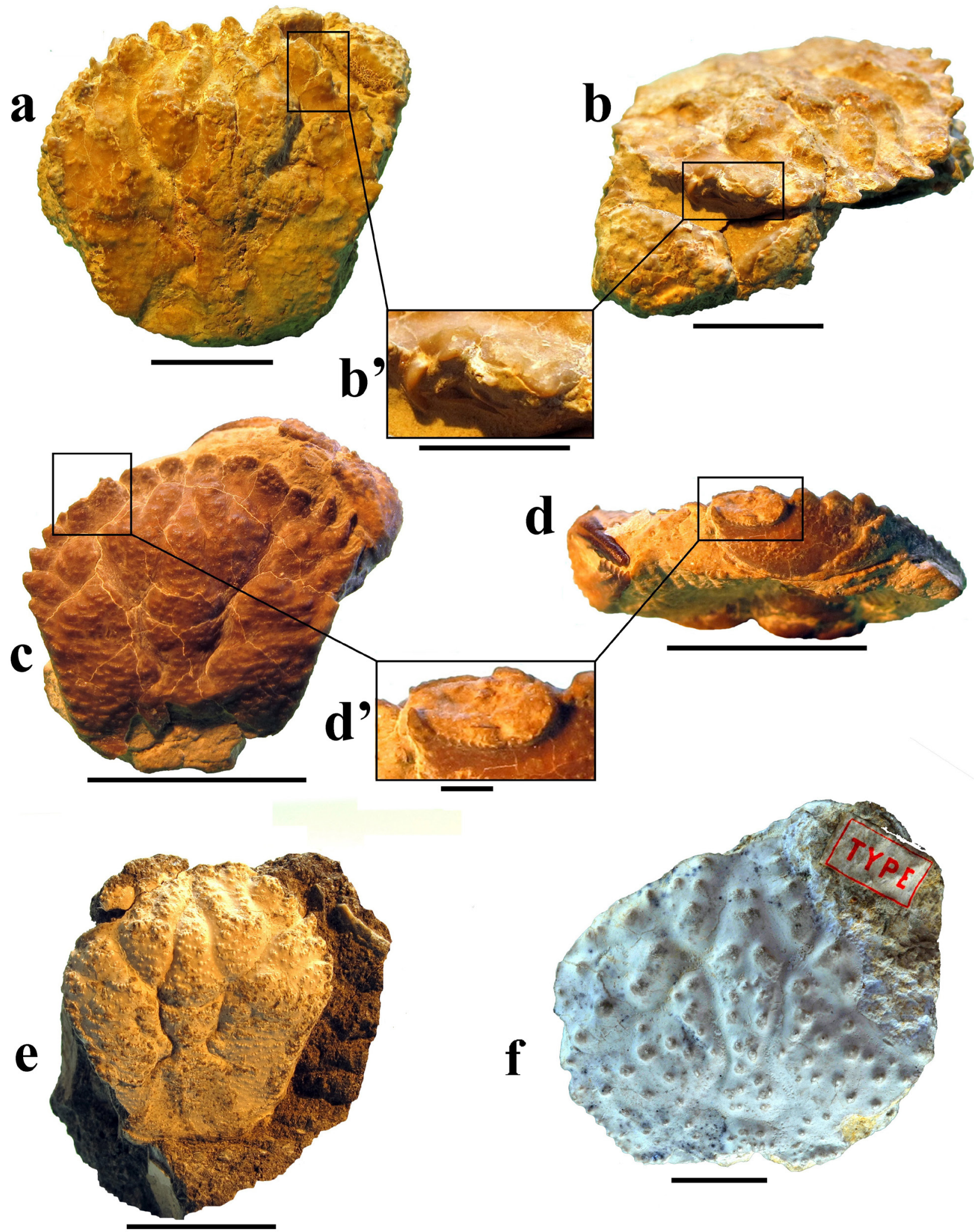

Figure 4. a: Montezumella amenosi Via, 1959, AO C-022-1 dorsal view, Collbàs Fm., Bartonian ( late Eocene), La Pobla de Claramunt, Anoia (Catalonia); b: same sample fronto-lateral view; b': close -up of rigth orbit of the same sample; c: Montezumella sp. MGB 59628, dorsal view, Lutetian (middle Eocene), Vic zone, Osona (Catalonia) ex Alfons Onetti coll.; d: same sample infra-orbital view; d': close up of the left orbit; e: Montezumella scabra Quayle and Collins, 1981, AO C-230-1, Lutetian (middle Eocene), Arzignano, Vicentino (Italy); f: "Atelecyclus" gorodiskii Rémy, 1959 in Gorodiski and Rémy, 1959, holotype MNHN R03847, dorsal view, Lutetian (middle Eocene), Pougnar (Senegal). Scale bar $=10 \mathrm{~mm}($ except for b'=5 mm; d' $=1 \mathrm{~mm}$ ). 

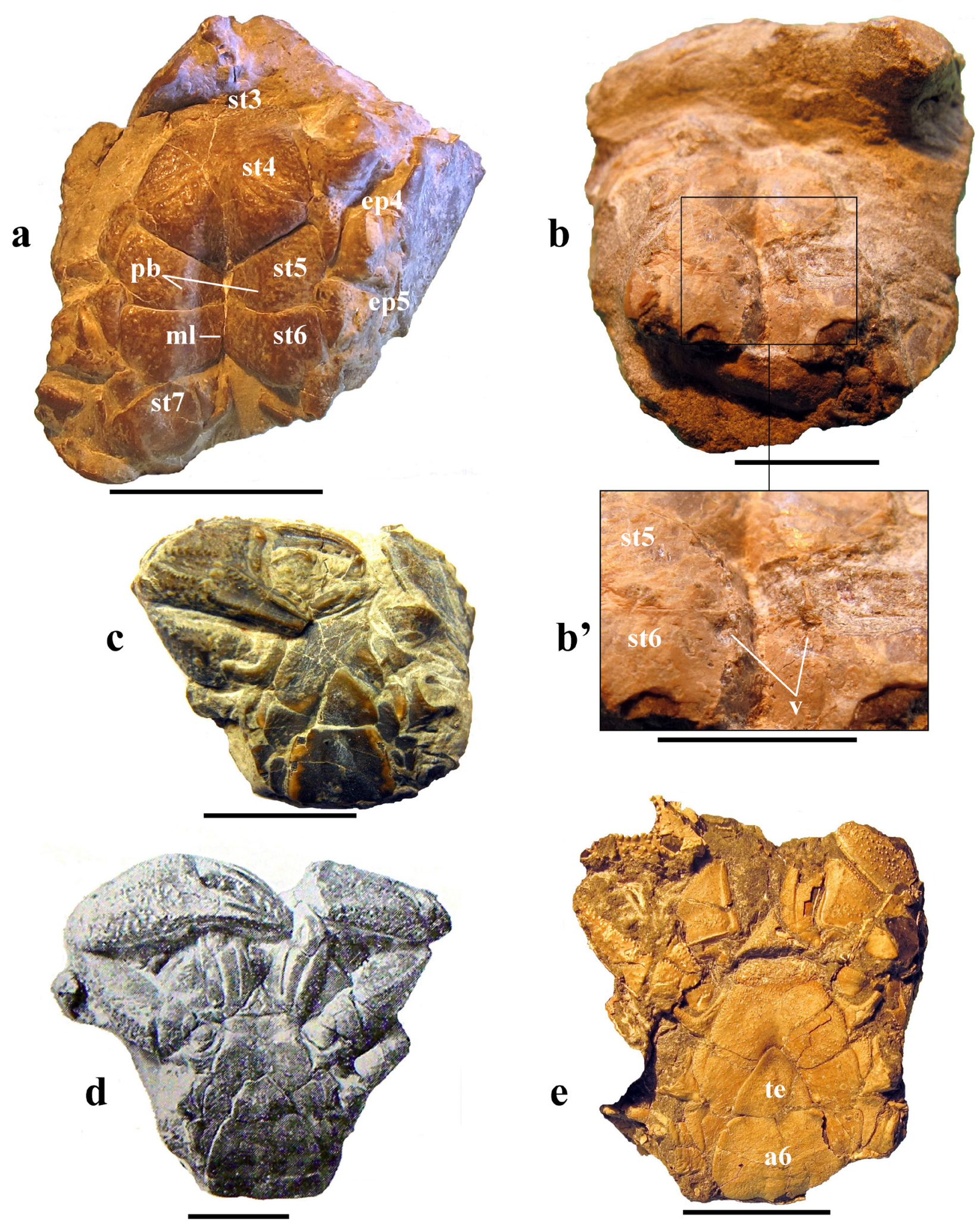

Figure 5. a: Montezumella sp. MGB 59626, male ventral view, Lutetian (middle Eocene), Vic zone, Osona (Catalonia); b: Montezumella sp. MGB 59627, female ventral view, Lutetian (middle Eocene), Vic zone, Osona (Catalonia) ex Alfons Onetti coll.; b': close up of sternum of same sample; c: Montezumella sp., private collection, female ventral view, Lutetian (middle Eocene), Vic zone, Osona (Catalonia); d: Montezumella amenosi Via, 1959, female ventral view, Collbàs Fm., Bartonian (late Eocene), La Pobla de Claramunt, Anoia (Catalonia), figured by Via in 1969 (reproduced with permission of Pirineos); e: Montezumella sp. MGB 59629, female ventral view, Bartonian (late Eocene), Huesca, Aragón (Spain). Abbreviations: a: abdominal somite, ep = episternites, $\mathrm{ml}=$ median line, $\mathrm{pb}=$ press button, $\mathrm{st}=$ thoracic sternites, te $=$ telson. Scale bar $10 \mathrm{~mm}($ except for b' $=5 \mathrm{~mm})$. 
2008, that was erected as new combination for Stintonius (= Plagiolophus) markgrafi Lörenthey, 1907, previously placed into Eucratopsinae (Panopeidae) as Glyphithyreus (= Plagiolophus) markgrafi (Karasawa and Kato, 2003, p. 144) was posteriorly moved to Cheiragonidae (Karasawa and Schweitzer, 2004, p. 144-146, f. 1.7; Vega et al., 2008, p. 56, f. 3, pl. 2, f. 13; De Grave et al., 2009, p. 31; Feldmann et al., 2011, p. 335-336, f. 7).

Stintonius Collins, 2002, erected to accommodate Portunites subovata (Quayle and Collins, 1981) and placed in Portunidae, was questionably transferred by Collins (2002, p. 86) to Cheiragonidae (Quayle and Collins, 1981, p. 749750, p. 105, f. 2; Schweitzer and Feldmann, 2000, p. 637; De Grave et al., 2009, p. 31). Pirulella Feldmann, Schweitzer and Encinas, 2010, was also included in Cheiragonidae on the basis of similarities with Montezumella and Erimacrus (Feldmann et al., 2010, p. 346-347, f. 7).

Although none of these genera preserve ventral structures or appendages, we disagree with these inclusions, being convinced that only Telmessus White, 1846, and Erimacrus Benedict, 1892, belong to the family Cheiragonidae. In particular, absence of females of the above-mentioned fossil species that could show the diagnostic sternal and abdominal cheiragonid structures, does not allow identification with confidence. Thus, assignment of these fossil genera to Cheiragonidae is not accepted here. A possible inclusion in Montezumellidae n. fam. is neither adopted.

Atelecyclus gorodiskii Rémy, 1959 in Gorodiski and Rémy, 1959 (Plate 1) from Eocene of Senegal, treated as Atelecyclidae (Rémy, 1959 in Gorodiski and Rémy, 1959, p. 318, p. 19a, f.2), deserves attention. The species was re-examined by Schweitzer and Feldmann (2010, p.402404, f. 1 B) and tentatively assigned to genus Calappilia A. Milne-Edwards in De Bouillé, 1873 (Calappidae De Haan, 1833). Atelecyclus godoriskii presents a carapace "légèrement arquée dans ses deux dimensions" (slightly arched in its two dimensions) which, although the frontal margin is absent, is suspected to be as wide as long. Other characters are: well-marked mesogastric region defined by grooves; apparently well-developed protograstric lobes with an oblique ridge, possibly formed by a median protogastric groove; metagastric and urogastric regions distinct, well defined, narrowing backwards until the cardiac region, which is large, and both bounded by grooves forming a continuous axial line; dorsal surface covered by granules; and posterolateral margin decorated with a row of tubercles. This combination of features excludes its belonging to Calappidae and suggests that $A$. gorodiskii could be related to Montezumellidae n. fam., where it is questionably placed herein. On the other hand A. gorodiskii, represented only by a fragmentary carapace, does not match with the diagnosis of genus Atelecyclus (Salva and Feldmann, 2001, p. 4749; Števčić, 2005, p. 32; Tavares and Cleva, 2010, T. 1). Consequently, until new material is available, we retain tentatively this taxon as "Atelecyclus" gorodiskii.
3.3. Comparisons of Montezumellidae n. fam. with other eubrachyuran families

Montezumellidae $\mathrm{n}$. fam. is compared with families that have similar thoracic structures and similar dorsal characters. Montezumellidae $\mathrm{n}$. fam. cannot be accommodated in Trichopeltarioidea Tavares and Cleva, 2010, whose front is cut into three teeth (versus four teeth in Montezumellidae), epibranchial teeth are very prominent (versus small or subequal in Montezumellidae) and sternal sutures 4/5 and 5/6 are incomplete (versus $4 / 5$ and 5/6 complete in Montezumellidae), pattern of dorsal features is distinct, the carapace being subpentagonal and inflated (versus subhexagonal and flattened in Montezumellidae) (Tavares and Cleva, 2010, T. 1).

Guinot (1979) who interpreted the sutures of thoracic sternites as a key character at higher level in Brachyura, proposed a division into four groups, the first embracing the genera with uninterrupted transverse sternal sutures $4 / 5$ to $7 / 8$. Several families were listed in this group, for example Atelecyclidae Ortmann, 1893, Corystidae Samouelle, 1819 and Cancridae Latreille, 1802 (Guinot, 1979, p. 81-86, T. 1). Montezumellidae $\mathrm{n}$. fam. offers this precise pattern. In contrast, Telmessus and Cheiragonus were diagnosed by Guinot $(1979$, p. 88 ) by sutures $4 / 5$ and $5 / 6$ that are "presque jointives" (almost joined) and sutures $6 / 7$ and 7/8 that are complete.

The presence of complete or almost complete sternal sutures was regarded as plesiomorphic (Guinot, 1979). Although sharing a similar pattern of narrow sternum and thoracic sternal sutures, Corystoidea Samouelle, 1819 (type genus: Corystes Bosc, 1802) differs from Montezumellidae in the absence of a sterno-abdominal cavity (well-marked in Montezumellidae) and the absence of abdominal locking (presence of a press- button in Montezumellidae). In addition, Corystes has lateral margins that are armed along its entire length, a very different bifid frontal margin, carapace inflated and regions not well-marked, incomplete orbits and male abdominal somites 3-5 fused (Guinot, 1979, p. 132, Pl. 9, f. 1, Števčić, 2005; Guinot, De Angeli and Garassino, 2007, fig. 1).

Kraussinae Ng, 1993 (Xanthidae MacLeay, 1838) has also uninterrupted sternal sutures 4/5-7/8. Although it presents superficial similarities with Montezumellidae notably in dorsal ornamentation, and frontal as well as lateral margins, it differs in many characters, such as the suture 3/4 that is complete (incomplete in Montezumellidae), and in any case, its current status as Xanthidae is confirmed $(\mathrm{Ng}$, 1993, Števčić, 2005, Ng et al., 2008).

Pilumnoides Lucas, 1844 in H. Milne Edwards and Lucas, 1844 (Pilumninoididae Guinot and Macpherson, 1987) possesses a narrow thoracic sternum and complete sutures $4 / 5$ to $7 / 8$; squamous appearance of carapace, well-marked axial line of grooves along the well-defined protogastric, metagastric and urogastric lobes, well defined mesogastric region, and tuberculated chelipeds with keeled 
propodus. But Pilumnoides differs from Montezumellidae in having an incomplete suture $2 / 3$ which is complete in Montezumellidae; episternites fairly developed and without sutures, instead of well-developed with marked sutures of Montezumellidae; a lower fronto-orbital ratio than Montezumellidae; ischium-merus fused instead of a free articulation in Montezumellidae; press button placed at mid length of sternite 5 in Pilumnoides, which is placed near the suture 5/6 in Montezumellidae; and shorter dactylus of first ambulatory leg compared to that of Montezumellidae. Moreover, the current status of Pilumnoides Lucas, 1844 (Pilumninoididae Guinot and Macpherson, 1987) in Pseudozioidea (Ng et al., 2008) discards the relationship with Montezumellidae. In our opinion, except for members of Cancroidea Latreille, 1802, the same would be said for other genera included by Guinot (1979, p. 83-86) into this first group of taxa with uninterrupted transverse sternal sutures $4 / 5$ to $7 / 8$. The current status of Thia Leach, 1815 (Thiidae Dana, 1852), Carpilius Desmarest, 1823 (Carpiliidae Ortmann, 1893), Daira De Haan, 1833 (Dairidae Serène, 1965) and Paraxanthus Lucas, in H. Milne Edwards and Lucas, 1844 (Xanthidae MacLeay, 1838), discards also any relationship with Montezumellidae.

Two primitive families, Marocarcinidae Guinot, De Angeli and Garassino, 2008, and Componocancridae Feldmann, Schweitzer and Green, 2008, neither of them can accommodate Montezumellidae. Both families differ in having interrupted sternal suture $5 / 6$, and different angle of sternites $4 / 5$ to $7 / 8$ than in Montezumellidae; other important differences are the very dissimilar dorsal pattern without well-defined regions which in contrast are well-marked in Montezumellidae (Guinot et al., 2008; Feldmann et al., 2007; Feldmann et al., 2008).

In conclusion, Montezumellidae possesses a primitive thoracic sternal pattern, and without going in to previous works relating Montezumella with Atelecyclidae (Rathbun, 1930b, Via, 1969, 1970, Quayle and Collins, 1981), we compare Montezumellidae n. fam. with Cancroidea Latreille, 1802 (sensu Guinot et al., 2008; Schubart and Reuschel, 2009); this is Atelecyclidae Ortmann, 1893, and Cancridae Latreille, 1802, which are considered as primitive families (Guinot, 1979, p. 81, 137; Števčić, 2005, p. 8, 12, 136). Atelecyclidae, which was attributed to Corystoidea, was transferred to Cancroidea by Guinot et al. (2008, p. 25-30).

Montezumellidae n. fam. shares with families of Cancroidea several characters; for instance, a more or less narrow, elongate and metamerised thoracic sternum, a median line present from sternite 4 to 8 , a trilobed supraorbital margin, a similar continuous axial line of grooves along lobes from protogastric to cardiac regions, and keeled propodus of first pereiopod. Nevertheless, cancroid families differs from Montezumellidae in having sternal suture $2 / 3$ that are laterally marked in Atelecyclidae and absent in Cancridae, (complete in Montezumellidae); in males, fused abdominal somites 3 to 5 (free in Montezumellidae); a different pattern of carapace, usually wider than long in Cancridae, and smooth in both families Cancridae and Atelecyclidae, (as wide as long and profusely ornate with strong granules, tubercles and ridges in Montezumellidae); a front usually trilobed in Cancroidea (four-lobed to four toothed in Montezumellidae); a lower fronto-orbital ratio in Cancroidea than in Montezumellidae; chelipeds isochelous (Cancridae) or homochelous (Atelecyclidae), (conspicuously heterochelous in Montezumellidae) (see Rathbun, 1930a, p. 85, f., 2-3-4-5; Tavares and Cleva, 2010, T. 1; Schram and Ng, 2012, f. 3).

In spite of these differences, we consider that the similar thoracic features suggest a certain degree of relationship between Montezumellidae and Cancroidea. We propose to place the new family tentatively in Cancroidea.

\section{Systematic palaeontology}

\author{
Order Decapoda Latreille, 1802 \\ Infraorder Brachyura Latreille, 1802 \\ Superfamily ?Cancroidea Latreille, 1802 \\ Family Montezumellidae n. fam. \\ Genus Moianella new genus
}

Etimology. From Moià, village of Bages (Catalonia, NE of Iberian Peninsula).

Diagnosis. Carapace subhexagonal, ovate, slightly longer than wide, flattened in both longitudinally and transversally; maximum width at mid-length of carapace; regions well defined; dorsal surface ornamented with tubercles, large granules and rows of various granules forming short squamous ridges. Dorsal regions well defined, hepatic region slightly swollen; protogastric lobes inflated, anterior half of both lobes sub-divided longitudinally by a median groove forming four short ridges that reaches the four frontal teeth respectively; mesogastric region slender, reaching the frontal margin; metagastric regions inflated, urogastric region narrow, both well delimited and bounded laterally by a groove that connect the cervical groove with the branchiocardiac groove, forming an axial continuous line. Cardiac region large. Epibranchial lobes inflated. Front relatively large, four-toothed with four acute spiny teeth. Orbits oval, oblique, complete, supra-orbital margin with two fissures; prominent acute sub-triangular inner orbital tooth with serrated outer margin, acute and prominent supraorbital tooth and finely laterally serrated outer tooth; continuous serrated orbital corner and infraorbital margin bearing a prominent inner infra-orbital tooth. Anterolateral margin slightly convex, short, armed with four strong and acute teeth. Posterolateral margin straight, stepped, converging backwards, ornamented with a row of prominent tubercles with re-entrant of fifth pereiopod. Posterior margin short, rimmed, convex. Mesobranchial and metabranchial regions slightly inflated. Toracic sternum narrow, granulated. Sternites 1-2 triangular; sternite 3 flat, 
well developed laterally; sternite 4 big, vaulted, laterally rimmed, deep sterno-abdominal cavity reaching two thirds of its length. Sternite 5 subtrapezoidal. Sternites 4-5 with well-developed episternites with suture complete. Suture 2/3 complete, suture $3 / 4$ visible only laterally; sutures $4 / 5$ and $5 / 6$ complete, sutures $6 / 7$ and $7 / 8$ unknown but supposedly complete. Press button on sternite 5 near suture $5 / 6$. Median line present at the sterno-abdominal cavity reaching sternite 4. Pterygostome subtrapezoidal, granulated; buccal collar of pterygostome rimmed at inner margin and finely serrated at outer margin. Abdominal somite 6 sub-rectangular with central socket in distal margin. Right cheliped: merus robust, subtriangular in section, inner surface concave, outer surface granulated and ridged; carpus strong, massive, three acute and spiny distal teeth, forward directed at the inner, upper and lateral outer angle, outer surface strongly convex coarse granulated; manus strong, upper margin with unknown spines or tubercles (scars), outer surface almost smooth except for a few scattered tiny granules; two transversal carinae: a medial one from the proximal margin to the mid-length of the manus and the second one parallel to the lower margin reaching the fixed finger; fixed finger with five teeth, outer surface with two carinae; movable finger with five teeth, as long as manus, upper margin with two rows of spines extend half distance to tip of finger. First ambulatory leg slender, sub-rectangular in section, long as propodus, dactylus acute.

Discussion. Moianella n. gen. shares with Montezumella Rathbun, 1930b similar carapace pattern that is almost flattened, ovate elongate, the same ornamentation with more or less strong granules or tubercles at the anterior half of carapace and ridges of tubercles at the posterior part giving a squamous aspect to the carapace; large and strongly four toothed front with median notch, trilobed supraorbital margin with two fissures, orbits closed; short and four toothed anterolateral margin, almost straight and unarmed posterolateral margin; well defined gastric process with anteriorly subdivided protogastric lobes by a groove; sharp mesogastric region reaching the frontal median notch; metagastric region inflated and urogastric region narrower, both distinct, and large cardiac region, all of them bounded by the characteristic sub parallel axial line of grooves; narrow and elongate sternum with median line reaching the sternite 4 , metamerised, sutures $2 / 3$ and $4 / 5$ to $7 / 8$ complete, and also the long, downward directed episternites. Despite the holotype of Moianella is not completely preserved in its ventral part, we assume that it follows the same pattern than in Montezumella.

Nevertheless, Moianella can be clearly distinguished from Montezumella for the big size (2 to 3 times) of the new genus when compared with Montezumella. In addition, the sharp and long spiny frontal teeth are usually blunt in the latter (even if M. tubulata Rathbun, 1930b has spiny and longer frontal teeth than other species of Montezumella). Also the anterolateral margin is armed with four subequal conical tooth in Moianella, while in Montezumella they decrease in size, being the last anterolateral tooth the smallest ones. Chelipeds are somewhat different between the two species: whereas in Moianella the carpus has strong tubercles, in Montezumella it is finely granulated and also the propodus is strongly tuberculated in its upper margin and slightly granulated between the carinae of the outer margin in Moianella, being usually profusely granulated in Montezumella. The differences are sufficient to propose a new genus for this new taxon.

\section{Moianella cervantesi new species}

Figure 6: a, b, c, d

Etymology. Dedicated to Manuel and Antonio Cervantes, who found and donated the holotype.

Diagnosis. as for the genus

Description. Carapace subhexagonal, elongate, ovate, slightly longer than wide. Slightly convex longitudinally, mainly at posterior part of carapace; flattened transversally. Regions well defined by shallow grooves and inflations. Dorsal surface ornamented with large granules or tubercles at the median areas of carapace, granules with spiny tip forward directed in the anterior areas of carapace and rows with various granules forming short irregular, squamous ridges at the posterior third of carapace. Hepatic region slightly inflated. Protogastric lobes inflated, well defined and bounded by the hepatogastric and cervical grooves, anterior half of both, subdivided longitudinally by an oblique median groove that reaches the frontal margin between the median and submedian frontal teeth, resulting four ridges that reaches the four frontal teeth respectively; mesogastric region narrow, sharp at the end when reaching the median frontal notch; metagastric region subtrapezoidal inverted, urogastric region short, narrow, bounded by two swellings, both regions well delimited and bounded laterally by grooves that form a continuous characteristic axial line connecting cervical groove with the branchiocardiac groove. Epibranchial lobes slightly inflated. Mesobranchial and metabranchial regions slightly swollen. Cardiac region subhexagonal, flat. Intestinal region flat. Front large, with four long, acute and sharp spiny teeth forward projected, divided by a U-shaped median notch. Orbits small, oblique, with two fissures on the supraorbital margin; prominent long, acute subtriangular inner orbital tooth, with serrated outer margin; long, sharp supraorbital tooth; outer orbital tooth sharp, finely serrated laterally, continuous serrated orbital corner and infra-orbital margin bearing a prominent inner infra-orbital tooth. Anterolateral margin short, slightly convex armed with four strong sub-equal, conical, sharp teeth, forward directed; last anterolateral tooth bifid, outer tip shorter than the inner tip. Posterolateral margin straight converging backwards, stepped, ornamented with a row of prominent tubercles and short ridges, with marked re-entrant of fifth periopod. Posterior margin convex, shorter than frontal margin. Pterygostome subtrapezoidal, granulated; buccal collar of pterygostome rimmed at inner margin and 

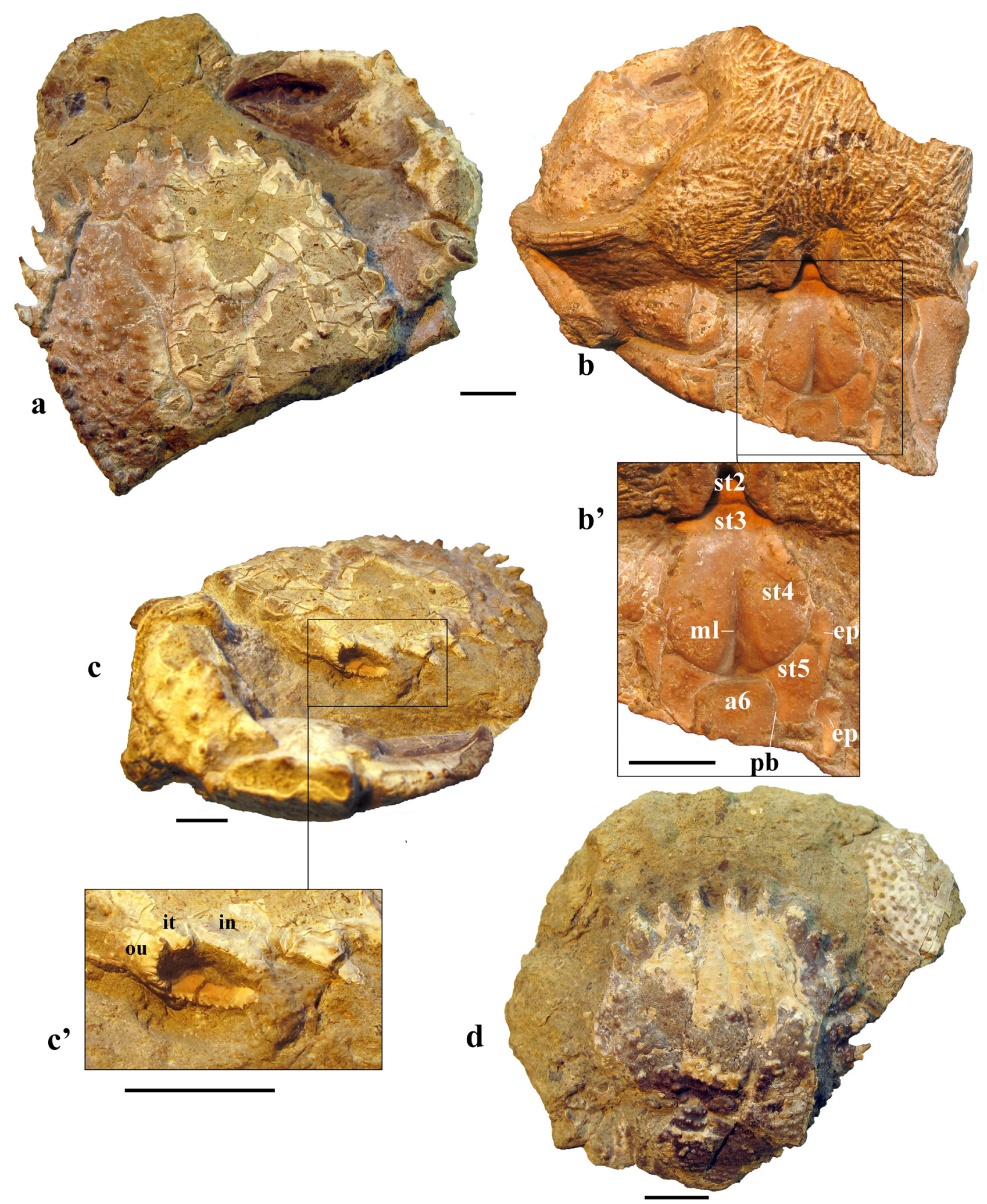

Figure 6. a: Moianella cervantesi n. gen., n. sp. Holotype MGB 59624 dorsal view, Priabonian (late Eocene), Moià, Bages (Catalonia); b: same sample ventral view; b': close up of sternum of same sample; c: fronto-orbital view of the same sample; c': close up right orbit of same sample; d: Moianella cervantesi n. gen., n. sp. paratype MGB 59625 dorsal view, Priabonian ( late Eocene), Moià, Bages (Catalonia). Abbreviations: a = abdominal somite, $\mathrm{ep}=$ episternites, in = inner-orbital tooth, it $=$ intra-orbital tooth, ou $=$ outer-orbital tooth, $\mathrm{ml}=$ median line, $\mathrm{pb}=$ press button, $\mathrm{st}=$ thoracic sternites. Scale bar: $10 \mathrm{~mm}$. 
finely serrated at outer margin. Thoracic sternum narrow, elongate, slightly granulated. Sternites 1-2 subtriangular, flat; sterno-abdominal cavity deep, reaching almost the anterior portion of sternite 4 , median line present. Sternite 3 flat, well developed laterally. Sternite 4 vaulted, elongate, more than three times longer than sternite 3, lateral margins longitudinally rimmed. Sternite 5 subtrapezoidal, forming an angle of $65^{\circ}$ with the sternite 4 and an angle of $50^{\circ}$ with the sternite 6 . Episternites 4 and 5 narrow, long and downwards directed, suture with sternites 4-5 complete. Suture $2 / 3$ complete; suture $3 / 4$ visible only laterally in the notch that divides both; suture $4 / 5$ complete. Press button visible on sternite 5 near suture $5 / 6$. Abdominal somite 6 subrectangular, pocket on the upper margin. Right cheliped: merus robust, subtriangular in section, inner surface concave, outer surface granulated and ridged; carpus strong, massive, three acute and spiny distal teeth, forward directed at the inner, upper and lateral outer angle, outer surface strongly convex coarse granulated; manus strong, upper margin with unknown spines or tubercles (scars), outer surface almost smooth except for a few scattered tiny granules; two transversal spiny carinae: a medial one from the proximal margin to the mid length of the manus and the second one parallel to the lower margin reaching the fixed finger; fixed finger with five teeth, outer surface with two carinae; movable finger with five teeth, as long as manus, upper margin with two rows of spines extend half distance to tip of finger. First ambulatory leg slender, sub-rectangular in section, long as propodus, dactylus acute.

Material. Holotype MGB 59624 and paratype MGB 59625.

Measurements (in mm). Holotype MGB 59624, carapace length $=56$ (uncomplete), width $=57$, orbitofrontal width $=42$, frontal width $=30$. Paratype MGB 59625 Carapace length $=40$, width $=37$, orbito-frontal width $=$ 32 , frontal width $=23$.

\section{Conclusions}

The main objective of this paper is to describe the new taxon Moianella cervantesi n. gen., n. sp. and not a revision of the different species of Montezumella, for this is beyond the scope of this study. The need of placing the new taxon within a family and considering its similarities with Montezumella have inevitably led us to review the previous familial placement of this genus and to propose the erection of a new family that include both genera.

There is no evidence yet, as it was claimed for Montezumella, of Cheiragonidae members in the fossil record. Montezumellidae has been revealed as a homogeneous basal eubrachyuran family, appearing in warm waters of the Mediterranean area during the middle Eocene. It would not be surprising to find new specimens in lowermost levels, and being widely dispersed westward during the late Eocene and Oligocene, reaching the Pacific Ocean via the Caribbean and Straits of Panamá, as the fossil record indicates.

\section{Acronyms}

MGB: Museu de Geologia de Barcelona. MNHN: Muséum national d'Histoire naturelle (Paris). AO: À. Ossó collection.

\section{Acknowledgments}

We thanks Danièle Guinot (MNHN, Paris) whose comments and suggestions improved greatly the first draft of manuscript. Also, we thank Manuel and Antonio Cervantes (Sant Cugat del Vallès, Catalonia) who found and kindly donated the holotype; Sylvain Charbonnier (MNHN, Paris), Alfons Onetti (Santa Maria de Palautordera, Catalonia), Josep Lagares (Mataró, Catalonia) and Ferràn Palero (CSIPUV, Valencia, Spain) kindly donated important comparative samples and provided photographic material; Josep Sanjuan (UB, Barcelona, Catalonia) and David Albalat (El Vendrell, Catalonia) provided and adapted figures of map location and geological sketch; and Torrey Nyborg (LLU, California) provided important documentation and helped us with the English language and useful comments. Finally we thank Francisco Vega (UNAM, Mexico) and Alessandro Garassino (MSN, Milano, Italy) whose critical and constructive review helped to improve the definitive work.

\section{References}

Benedict, J.E., 1892, Corystoid crabs of the genera Telmessus and Erimacrus: Proceedings of the United States National Museum, $15,223-230$

Beschin, C., Busulini, A., De Angeli, A., Tessier, G., 2002, Aggiornamento ai Crostacei Eocenici di Cava "Main" di Arzignano (Vicenza Italia Settentrionale) (Crustacea, Decapoda): Studi e Ricerche, Associazione Amici del Museo, Museo Civico "G. Zannato", Montecchio Maggiore (Vicenza), 7-28.

Bosc, L.A.G., 1802, Histoire naturelle des Crustacés, contenant leur description et leurs moeurs, avec figures dessinées d'après nature: De Guilleminet, Paris, 1, 1-258; 2, 1-296.

Bouvier, E.L., 1942, Les crabes de la tribu des "Corystoidea": Mémoires de l'Académie des Sciences de l'Institut de France, 65(4), 1-52.

Cascella, A., Dinarès-Turell, J., 2009, Integrated calcareous nannofossil biostratigraphy and magnetostratigraphy from the uppermost marine Eocene deposits of the southeastern Pyrenean foreland basin: evidences for marine Priabonian deposition: Geologica Acta, 7(1-2), 281-296.

Collins, J.S.H., 2002, A taxonomic review of British decapod Crustacea: Bulletin of the Mizunami Fossil Museum, 29, 81-92.

Collins, J.S.H., Donovan, S.K., 2005, Eocene crabs from Bonaire: Scripta Geologica, 129, 127p.

Dana, J.D., 1852, Parts I and II, Crustacea: U.S. Exploring Expedition during the Years 1838, 1839, 1840, 1841, 1842, under the Command of Charles Wilkes, U.S.N.: C. Sherman, Philadelphia, 13, 1-1618. 
De Angeli, A., 1995, Crostacei dell'Eocene superiore di "Frontanella" di Grancona (Vicenza - Italia settentrionale): Studi e Ricerche, Associazione Amici del Museo Civico "G. Zannato", Montecchio Maggiore, (VI), 7-24.

De Bouillé, R., 1873, Paléontologie de Biarritz : Compte Rendu Travaux Congrès Scientifique de France, Pau, 39e session, 11p.

De Grave, S., Pentcheff, N.D., Ahyong, S.T., Chan, T. Y., Crandall, K.A., Dworschak, P.C., Felder, D.L., Feldmann, R.M., Fransen, C.H.J.M., Goulding, L.Y.D., Lemaitre, R., Low, M.E.Y., Martin, J.W., Ng, P.K L., Schweitzer, C.E., Tan, S.H., Thudy, D.T., Wetzer, R., 2009, A classification of living and fossil genera of decapods crustaceans: Raffles Bulletin of Zoology, Supplement, 21, 1-109.

De Haan, W., 1833-1850, Crustacea, in Siebold, P.F. de (ed.), Fauna Japonica sive descriptio animalium, quae itinere in Japoniam, jussu et auspiciis superiorum, quisummum in India Batava Imperium tenent, suscepto, annis 1823-1830, collegit, notis, observationibus et adumbrationibus, illsutravit. - ix-xvi, I-xxxi, vii-xvii + 243 p.; Lugdunum Batavorum (Arnz).

Desmarest, A.G., 1823, Crustacés Malacostracés, in F. G. Levrault et Le Normant, Strasbourg and Paris, Dictionnaire des Sciences Naturelles, $28,138-425$.

Feldmann, R.M., Green, R., Schweitzer, C.E., 2007, An unusual Albian (Early Cretaceous) crab from Montana: the earliest eubrachyuran?. Third Symposium on Mesozoic and Cenozoic Decapod Crustaceans - Museo di Storia Naturale di Milano, May 23-25, 2007: Memorie della Società Italiana di Scienze Naturali e del Museo Civico di Storia Naturale di Milano, 35(2), 28-29.

Feldmann, R.M., Schweitzer, C.E., Bennett, O., Frantescu, O.D., Resar, N., Trudeau., A., 2011, New Eocene Brachyura (Crustacea: Decapoda) from Egypt: Neues Jahrbuch für Geologie und Paläontologie Abhandlungen, 262(3), 323-353.

Feldmann, R.M., Schweitzer, C.E., Green, R., 2008, Unusual Albian (Early Cretaceous) Brachyura (Homoloidea: Componocancroidea new superfamily) from Montana and Wyoming, U.S.A.: Journal of Crustacean Biology, 28(3), 502-509.

Feldmann, R.M., Schweitzer, C.E., Encinas, A., 2010, Neogene decapod crustacean from Southern Chile: Annals of Carnegie Museum, 78(4), 337-366.

Gorodiski, A., Rémy, J.M., 1959, Sur les Décapodes éocènes du Sénégal occidental: Bulletin de la Société Géologique de France, 7(3), 315-319.

Guinot, D., 1977, Données nouvelles sur la morphologie, la phylogenèse et la taxonomie des Crustacés Décapodes Brachyoures: Université Pierre et Marie Curie, Paris, France, tesis doctoral, $486 \mathrm{p}$.

Guinot, D., 1979, Données nouvelles sur la morphologie, la phylogenèse et la taxonomie des Crustacés Décapodes Brachyoures: Mémoires du Muséum National d'Histoire Naturelle, A, Zoologie, 112, 1-354.

Guinot, D., De Angeli, A., Garassino, A., 2007, Hebertides jurassica n. gen., n. sp. (Crustacea, Decapoda, Brachyura) from the Middle Jurassic (Bathonian) of Normandy (France): Atti della Società Italiana di Scienze Naturali e del Museo Civico di Storia Naturale in Milano, 148(2), 241-260.

Guinot, D., De Angeli, A., Garassino, A., 2008, Marocarcinidae, a new eubrachyuran family, and Marocarcinus pasinii n. gen, n. sp. from the Upper Cretaceous (Cenomanian-Turonian) of Gara Sbaa, Southeastern Morocco (Crustacea, Decapoda, Brachyura): Atti della Società Italiana di Scienze Naturali del Museo Civico di Storia Naturale di Milano, 149(1), 25-36.

Guinot, D., Macpherson, E., 1987, Révision du genre Pilumnoides Lucas, 1844 , avec description de quatre espèces nouvelles et création de Pilumnoidinae subfam. nov. (Crustacea Decapoda Brachyura): Bulletin du Muséum National d'Histoire Naturelle, 4(9A/1), 211-247.

Karasawa, H., Kato, H., 2003, The family Goneplacidae MacLeay, 1838 (Crustacea: Decapoda: Brachyura): systematics, phylogeny, and fossil records: Paleontological Research, 7(2), 129-151.

Karasawa, H., Schweitzer, C.E., 2004, Revision of the genus Glyphithyreus Reuss, 1859 (Crustacea, Decapoda, Brachyura: Xanthoidea) and recognition of a new genus: Paleontological Research, 8(3), 143-154.
Latreille, P.A., 1802-1803, Histoire Naturelle, générale et particulière, des Crustacés et des Insectes. Ouvrage faisant suite aux oeuvres de Leclerc de Buffon, et partie du Cours complet d'Histoire naturelle rédigé par C. S. Sonnini, membre de plusieurs Sociétés savantes: Paris, Dufart, 5, 1-407.

Leach, W.E., 1815-1875, Malacostraca Podophthalmata Britanniae, or descriptions of such British species of the Linnean genus Cancer as have their eyes elevated on footstalks: 1-124.

Lörenthey, E., 1907, Palaeontologiai tanulmányok a harmadkorú rákok köréböl. V. Adatok Egyptom eocenkori rákfaunájához: Mathematikai és Természettudományi Közlemények, 29(2), 195-242.

Lörenthey, E., 1909, Beitrage zur Kenntnis der Eozänen Decapodenfauna Ägyptens: Mathematische und Naturwissenschaftliche, Berichte aus Ungarn, 25, 106-152.

Lörenthey, E., Beurlen, K., 1929, Die fossilen Decapoden der Lander der Ungarischen Krone: Geologica Hungarica, Series Palaeontologica, $3,420 \mathrm{p}$.

MacLeay, W.S.,1838, On the brachyurous decapod Crustacea brought from the Cape by Dr. Smith, in Smith, A. (ed.), Illustrations of the Annulosa of South Africa; being a portion of the objects of natural history chiefly collected during an expedition into the interior of South Africa, under the direction of Dr. Andrew Smith, in the years 1834, 1835 and 1836; fitted out by "The Cape of Good Hope Association for Exploring Central Africa": Smith, Elder, and Co., London, 53-71.

Milne Edwards, H., Lucas, H., 1842-1844, in A. d'Orbigny, Voyage dans l'Amérique méridionale dans le cours des années 1826-1833: Paris, 6 (1-39), Atlas, 9, 1-17.

Ng, P.K.L., 1993, Kraussinae, a new subfamily for the genera Kraussia Dana, 1852, Palapedia, new genus, and Garthasia, new genus (Crustacea: Decapoda: Brachyura: Xanthidae), with description of two new species from Singapore and the Philippines: The Raffles Bulletin of Zoology, 41(1), 133-157.

Ng, P.K.L., Guinot, D., Davie, P.J.F., 2008, Systema Brachyurorum: Part I. An annotated checklist of extant brachyuran crabs of the world: The Raffles Bulletin of Zoology, Supplement, 17, 1-286.

Ortmann, A.E., 1893, Die Decapoden-Krebse des Strassburger Museum. VII. Theil. Abtheilung: Brachyura (Brachyura genuina Boas) II. Unterabtheilung: Cancroidea, 2, Section: Cancrinea, I. Gruppe: Cyclometopa: Zoologischen Jahrbuchern, Abtheilung fur Systematic, Geographie und Biologie der Thiere 7, 411-495.

Portell, R.W., Collins, J.S.H., 2002, A new species of Montezumella (Crustacea: Decapoda: Cheiragonidae) from the Upper Eocene Ocala Limestone of Florida: Proceedings of the Biological Society of Washington, 115, 594-599.

Puigdefàbregas, C., Muñoz, J.A., Marzo, M., 1986, Thrust belt development in the eastern Pyrenees and related depositional sequences in the southern foreland basin: London, International Association of Sedimentologists, Special Publications, 8, 229-246.

Puigdefäbregas, C., Muñoz, J.A., Vergés, J., 1992, Thrusting and Foreland Basin Evolution in the Southern Pyrenees, in McClay, K.R. (ed.), Chapman and Hall, Thrust Tectonics, 247-254.

Quayle, W.J., Collins, J.S.H., 1981, New Eocene crabs from the Hampshire Basin: Palaeontology, 24(4), 733-758.

Rathbun, M.J., 1930a, The Cancroid Crabs of America of the families Euryalidae, Portunidae, Atelecyclidae, Cancridae, and Xanthidae: United States National Museum Bulletin, 152, 1-609.

Rathbun, M.J., 1930b, Fossil decapod crustaceans from Mexico: Proceedings of the United States National Museum, 78, 1-10.

Rathbun, M.J., 1934, Fossil decapod crustaceans from Vitilevu, Fiji, 238241, in Ladd, H.S.(ed.), Geology of Vitilevu, Fiji: Honolulu, Hawaii, Bernice P. Bishop Museum Bulletin, 119, 238-241.

Rathbun, M.J., 1937, Cretaceous and Tertiary crabs from Panama and Colombia: Journal of Paleontology, II, 26-28.

Rémy, J.M., 1959 in Gorodiski, A., Rémy, J.M., Sur les Décapodes éocènes du Sénégal occidental: Bulletin de la Société Géologique de France 7(3), 315-319.

Salva, E.W., Feldmann, R.M., 2001, Reevaluation of the family Atelecyclidae (Decapoda:Brachyura): Kirtlandia, 52, 9-62. 
Samouelle, G., 1819, The entomologist's useful compendium, or an introduction to the British insects, etc.: T. Boys, London, 1-496.

Sanjuán, J., Martin-Closas, C., Serra-Kiel, J., Gallardo, H., 2012, Stratigraphy and biostratigraphy (charophytes) of the marineterrestrial transition in the Upper Eocene of the NE Ebro Basin (Catalonia, Spain): Geologica Acta, 10(1), 19-31.

Schram, F.R., Ng, P.K.L., 2012, What is Cancer?: Journal of Crustacean Biology, 32(4), 665-672.

Schubart, C.D., Reuschel, S., 2009, A proposal for a new classification of Portunoidea and Cancroidea (Brachyura: Heterotremata) based on two independent molecular phylogenies, in Martin, J.W., Crandall, K.A., Felder, D.L., (eds.), Decapod Crustacean Phylogenetics: Crustacean Issues, 18, 533-549.

Schweitzer, C.E., Feldmann, R.M., 2000, New fossil Portunids from Washington, USA, and Argentina, and a re-evaluation of generic and family relationships within the Portunoidea Rafinesque, 1815 (Decapoda:Brachyura): Journal of Paleontology, 74(4), 636-653.

Schweitzer, C.E., Feldmann, R.M., 2010, New fossil decapod crustaceans from the Remy Collection, Muséum National d'Histoire Naturelle, Paris: Geodiversitas, 32, 399-415.

Schweitzer, C.E., Feldmann, R.M., Garassino, A., Karasawa, H., Schweigert, G., 2010, Systematic list of fossil decapod crustacean species: Leiden (Brill), Crustaceana Monographs, 10, 222p.

Schweitzer, C.E., Salva. E.W., 2000, First recognition of the Cheiragonidae (Decapoda) in the fossil record and comparison of the family with the Atelecyclidae: Journal of Crustacean Biology, 20(2), 285-298.

Serène, R., 1965, Guide for curators of brachyuran collections in Southeast Asia: Applied Scientific Research Corporation of Thailand, Bangkok $1-65$.

Serra-Kiel, J., Mató, E., Saula, E., Travé, A., Ferràndez-Cañadell, C., Busquets, P., Samsó, J.M., Tosquella, J., Barnolas, A., Àlvarez-Pérez, G., 2003, An inventory of the marine and transitional Middle/Upper Eocene deposits of the Southeastern Pyrenean Foreland Basin (NE Spain): Geologica Acta, 1(2), 201-229.

Števčić, Z., 1988, The status of the family Cheiragonidae Ortmann, 1893: Oebalia, 14, N.S., 1-14.

Števčić, Z., 2005, The reclassification of brachyuran crabs (Crustacea: Decapoda: Brachyura): Natura Croatica, 14(1), 1-159.

Tavares, M., Cleva, R., 2010, Trichopeltariidae (Crustacea, Decapoda, Brachyura), a new family and superfamily of eubrachyuran crabs with description of one new genus and five new species: Papéis Avulsos Zoologia, 50(9), 97-157.

Travé, A., 1992, Sedimentologia, petrologia i geoquímica (elements traça $\mathrm{i}$ isòtops) dels estromatòlits de la Conca Eocena Sudpirinenca: Barcelona, Universitat de Barcelona, tesis doctoral, $395 \mathrm{p}$.

Travé, A., Ferràndez, C., Serra-Kiel, J., Zamarreño, I., 1994, Paleobiocenosis distribution in transitional environments: example from the Eocene of Northeastern Spain, in Mateucci, R., Carboni, M.G., Pignatti, J.S., (eds.), Studies on Ecolog y and Paleoecology of Benthic Communities: Bolletino della Società Paleontologica Italiana, Special Volume, 2, 331-341.
Travé,A., Serra-Kiel, J., Zamarreño, I., 1996, Paleoecological interpretation of transitional environments in Eocene carbonates (NE Spain): Palaios, 11, 141-160.

Van Straelen, V., 1933, Sur des Crustacés décapodes de l'Éocène supérieur de l'île Bonaire: Bulletin du Musée Royal d'Histoire Naturelle de Belgique, 9(23), 1-4.

Vega, F.J., Nyborg, T., Coutiño, M.A., Hernández-Monzón, O., 2008, Review and additions to the Eocene decapod Crustacea from Chiapas, Mexico: Bulletin of the Mizunami Fossil Museum, 34, 51-71.

Vergés, J., Marzo, M., Santaeulàlia, T., Serra-Kiel, J., Burbank, D.W., Muñoz, J.A., Gimenez-Montsant, J., 1998, Quantified vertical motions and tectonic evolution of the SE Pyrenean foreland basin, in Mascle, A., Puigdefäbregas, C., Luterbacher, H.P., Fernández, M. (eds.), Cenozoic Foreland Basins of Western Europe: London, Geological Society, Special Publications, 134, 107-134

Via, L., 1932, Els Crancs fòssils del Terciari de Catalunya: Butlletí de la Institució Catalana d'Història Natural, 32, 131-146.

Via, L., 1941, Los cangrejos fósiles de Cataluña: Boletín del Instituto Geológico y Minero de España, 55, 55-127.

Via, L., 1948a, Braquiuros fósiles de Barcelona y sus alrededores: Anales de la Escuela de Peritos Agrícolas, 7, 143-152.

Via, L., 1948b, A propósito de dos Braquiuros fósiles del Eoceno de la provincia de Barcelona: Estudios de Geologia, 4 (8), 283-286.

Via, L., 1959, Decápodos fósiles del Eoceno español: Boletín del Instituto Geológico y Minero de España, 70, 331-402.

Via, L., 1969, Crustáceos decápodos del Eoceno español: Pirineos, 9194, $480 \mathrm{p}$.

Via, L., 1970, Estudio paleontológico y bioestratigráfico de Montezumella amenosi, interesante braquiuro (Atelecyclidae) del Eoceno catalán: Acta Geológica Hispánica, 5, (1), 12-18.

Via, L., 1988, Els decàpodes, in Història Natural dels Països Catalans, 15 (Registre fòssil), 343-352. Barcelona.

White, A., 1846, Meeting of the Entomological Society, April 7, 1845: Annals of Natural History, 17, 497.

Manuscript received: September 28, 2012.

Corrected manuscript received: October 20, 2012.

Manuscript accepted: October 22, 2012. 